\title{
INFLUENCE OF ANTI-HEAT STRESS AGENTS ON GROWTH, IMMUNITY, LIPID OXIDATION AND SOME PHYSIOLOGICAL TRAITS IN JAPANESE QUAIL DURING HOT SUMMER SEASON
}

\author{
S. A. Abdel-Fattah ${ }^{1}$ and Zenat, A. Ibrahiem ${ }^{2}$ \\ 1- Poultry Production Department, Faculty of Agriculture, Ain Shams University, Cairo, Egypt, 2- \\ Poultry Production Department, Faculty of Agriculture, Zagazig University, Zagazig, Egypt
}

\section{SUMMARY}

The effect of anti-heat stress agents on growth, immunity, lipid peroxidation and some physiological traits in Japanese quail during hot summer season were investigated. A total of 360 one day old Japanese quail chicks were randomly distributed into six groups of 60 chicks, with almost similar initial average live body weight (LBW) in three replicates of 20 birds each. Experimental treatments included three vitamin $C(A A)$ levels $(0.0,0.5$ and $1 \mathrm{~g} / \mathrm{kg}$ diet) and two acetylsalicylic acid (ASA) levels $(0.0$ and $0.5 \mathrm{~g} / \mathrm{kg}$ diet $)$ in a factorial design (2x3). All groups were exposed to high ambient temperature of Egyptian summer season until the end of experimental period with the lay of the $1^{\text {st }}$ egg.

The result showed that, the highest $(P<0.05) L B W$ and body weight gain $(B W G)$ and the best feed conversion ratio (FCR), from 0 to 6 week of age (WOA), were observed for chicks of ASA or ascorbic acid (AA) at both levels. Moreover, chicks in control group consumed insignificantly less feed during the whole experimental period when compared with the non supplemented. Additionally, there was no significant difference between the low and high level of AA. Lower rectal temperature (RT) and respiration rate $(R R)$ were associated with dietary provision of either AA or ASA. Serum concentration of total protein, albumin, glucose, total lipids, cholesterol, uric acid and the activity of malondialdehyde (MDA) as well as, AST and ALT were significantly decreased in chicks received either ASA or AA indicating better protection of liver tissues from being destroyed in response to heat stress of summer season. On the other hand, significant increase in serum concentration of thyroid gland hormones $\left(T_{3}\right.$ and $\left.T_{4}\right)$ and their conversion ratio $\left(T_{3} / T_{4}\right.$ ratio) were detected comparable to the non supplemented control group. Chicks of either AA or ASA had higher total and IgG anti NDV antibodies seven d post- secondary NDV immunization. However, the relative weights of thymus, spleen and bursa were significantly increased with the addition of AA but not with ASA. Earlier age at sexual maturity and higher relative weights of reproductive organs (testis, ovary and oviduct) was found for the supplemented birds compared with the non supplemented ones. The interaction between $A A$ and ASA was significant for $L B W, B W G$, serum levels of glucose, cholesterol, total lipid and MDA and not significant for the FC, FCR, and serum total protein and its fraction during the whole experimental period. Moreover, insignificant difference was found between the high and low level of AA.

It could be concluded that, addition of either ASA or AA at the dosage of $0.5 \mathrm{~g} / \mathrm{kg}$ diet is practically effective in ameliorating the deleterious effects of hot summer and enhancing the general performance, immunity and physiological homeostasis of Japanese quail during the grower period.

Keywords: Quail, summer, anti-stress, immunity, antioxidant, physiology

\section{INTRODUCTION}

Heat stress is one of the most important factors adversely effecting overall production in many regions of the world. Large economic losses occur because of mortality, decreased production and reduces of immune response in relation to high environment temperature (Younis, 2007 a,b).

The expression of heat stress in poultry production can be described as "acute" or "chronic", acute heat stress refers to short and sudden periods of extremely high temperature, whereas chronic heat stress refers to an extended periods of elevated temperature (Aengwanich, 2007). Acute stress caused by sudden increases in temperature results in large number of death and evokes a wide range of behavioral, biochemical, physiological and molecular adjustments (Etches et al., 1995). The nature and magnitude of these adjustments depend upon the degree of heat stress imposed. Typical responses include elevations in plasma concentrations of corticosteroids (5-folds), protein, glucose, sodium and decrease in relative weights of adrenal, bursa, spleen and thyroid (Whitehead and Keller, 2003 and Abou El-Soud et al., 2006). At high ambient temperature, growth rate decreased as the results of the reduced appetite and food intake and respiratory rate increases, causing respiratory alkalosis (North and Bell, 1990 and Mebta and Sbingari, 1999). 
Several methods are available to elevate the negative effect of high environment temperature on performance of poultry. Because of the high cost and impracticality of cooling animal buildings, interesting dietary manipulations has increased. Vitamin, mineral and drug supplementation as a single or in combination have been investigated to alleviate the detrimental effects of high environmental temperatures. Use of these compounds to ameliorate or prevent bird stress is ethically important, and may also be of use in improving our understanding of the complex physiological and behavioral aspects of stress. However, the use of vitamins, minerals and other dietary substances may provide a less expensive, and thus more readily available, alternative to other anti-stress drugs, if they can be shown to remove or, at least, mitigate a harmful consequence of the stress response. Two previously tested compounds are ascorbic acid (AA) and acetyl salicylic acid (ASA) (Ali and Al-Qarawi (2010).

Studies have shown that, antioxidant nutrient supplementation; especially ascorbic acid or vitamin $\mathrm{C}$ (VC) can be used to attenuate the negative effects or environmental stress (Sahin et al., 2003). Ascorbic acid (AA) synthesizes in avian kidneys has been demonstrated to protect the birds from heat stress and improve disease resistance in birds by optimizing the function of the immune system (Wu et al., 2000 and Lohakare et al., 2005). The beneficial effect of supplemental ascorbic acid in stressful situations in poultry has been reported by (Mckee et al., 1997; Sahin, et al., 2003a, b). During heat stress the endogenous ascorbic acid produced is rapidly consumed and amount synthesized fall below bird's requirements. Pardue and Thaxton (1986) reported that ascorbic acid synthesis is inadequate under stress conditions such as low or high environmental temperature, humidity and parasitic infestation (Kultu and Forbes, 1993 and Sahin et al., 2002). There has been considerable interest in the possible nutritional role for ascorbic acid on the basis that endogenous synthesis may not be adequate to meet the full needs of poultry at all times or requirements for $\mathrm{VC}$ may be increased under certain circumstances as stressful conditions (Whitehead and Keller, 2003).

Ascorbic acid supplementation improved performance of heat challenged broiler chickens and lowered corticosterone level in the blood (Pardue et al., 1985). Thus, substantial attention has been paid to the role of nutritional additives to minimize the effect of heat stress. Dietary VC alleviated the effects of heat stress in poultry (Pardue and Thaxton, 1986). Ascorbic acid plays an important role in the synthesis of steroid hormones. These are responsible for mobilizing the energy needed for various vital functions, among other things, for maintaining body temperature. If there is a VC deficiency corticosteroids are formed inadequately. Moreover, corticosteroids and, indirectly VC, play an important role in immunity processes (Seeman, 1991). One of the hormonal responses to heat stress is an increase in the level of corticosterone in blood, the primary glucocorticoid hormone produced by the avian adrenal gland.

The other compound is acetylsalicylic acid (ASA), the active ingredient of Aspirin, which is a well known as an antipyretic drug (Weissmann, 1991). Aspirin inhibits prostaglandin synthesis and "resets the hypothalamic thermostat". It has been demonstrated that feeding ASA to chickens during heat stress lowers body temperature. Abou El-Soud et al. (2006) and Hassan et al. (2003) in laying Japanese quail and Tras et al. (2000) in broiler chicks reported that ASA supplemental decreased body temperature and improved the destructive effect of heat stress. But, McDaniel and Parker (2004) found no beneficial effect on broiler and broiler breeder performance, respectively.

Although many studies are available on broiler and chickens, little on growing Japanese quails chicks is available concerning these substances on physiological and immunological parameters. Thus the purpose of the present study was to determine the role of combined ascorbic acid (AA), and acetylsalicylic acid (ASA) treatment in minimizing the negative effects of heat stress on performance and some physiological and immunological status in Japanese quails raised (or reared) under hot summer condition.

\section{MATERIALS AND METHODS}

\section{Birds, Diet and Experimental Design:}

Three hundred sixty, one day old Japanese quail chicks were randomly distributed in a factorial design into six treatments $(2 \times 3)$. There were three replicates of 20 birds each. Experimental treatments included three vitamin $C$ levels $(0.0,0.5$ and $1 \mathrm{~g} / \mathrm{kg}$ diet $)$ and two ASA levels (0.0 and $0.5 \mathrm{~g} / \mathrm{kg}$ diet $)$ in factorial $(3 \times 2)$ design. At the age of 35 days birds were transferred to the breeding cage until the age of $1^{\text {st }}$ egg. All groups were exposed to high ambient temperature of Egyptian summer season until the end of experimental period with the lay of the $1^{\text {st }} \mathrm{egg}$. Feed and water were provided for ad libitum consumption throughout the experimental period. The grower diet was formulated to meet al.1 requirements recommended by NRC 
(1994). Chicks were maintained on a light cycle of 16L: 8D.

\section{Data Collection:}

The individual live body weight (LBW) and feed consumption (FC) were biweekly recorded at the beginning of the experiment till the $6^{\text {th }}$ wk of age then; the body weight gain (BWG) and feed conversion ratio (FCR) were calculated. Rectal temperature (RT) was measured by inserting a probe of electronic thermometer two $\mathrm{cm}$ inside the cloaca for a minute. Respiration rate (RR) was measured by counting the movement of body wall for a minute. Both measurements were taken simultaneously, at two wk intervals. All chicks were vaccinated against Newcastle Disease virus (Lasota strain vaccine) at day 21 and repeated at day 28. Serum samples were collected seven days after the first and second immunization respectively to evaluate the primary and secondary antibody responses (Hitchner et al. 1980). The antibody responses were measured using a microheamagglutination technique as described by Dix and Taylor (1996). The antibody data were expressed as the $\log 2$ of the reciprocal of the highest dilution given visible agglutination. The total mercaptoethanol-sesitive (MES, presumably IgM) and mercaptoethanolresistsnt (MER, presumably IgG) anti-NDV.

At the 6th WOA samples of birds (males and females) were randomly taken from each treatment, weighed, slaughtered and their feather were removed. The bursa of Fabricius, spleen, thymus, testis, ovary and oviduct were removed and weighed to the nearest of milligram, then expressed as percentage of live body weight. Serum samples were assigned for determination of glucose, total protein, albumin, total lipids, cholesterol, aspartate aminotransferase (AST) and alanin aminotransferase, (ALT) using available commercial kits. Globulin was calculated by subtraction of serum albumin from total protein. The determination of serum malondialdehyde (MDA) as a marker of lipid peroxidation was based on a colorimetric method described by Uchiyama and Mihara (1978). Spectrophotometer was adjusted to read the absorbance at a wave length of 535 $\mathrm{nm}$. Serum concentration of triiodothyronine (T3) and thyroxine (T4) were determined using commercial enzyme immunoassay test kit produced by Cal-Tech Diagnostics, Inc. Chino, California, USA. The age at sexual maturity was measured in days as indicated by the lay of 1st egg.

\section{The temperature- humidity index (THI):}

Values inside the quail production unit during the period of the experimental work were recorded during summer season. The temperature-humidity index (THI) was estimated according to livestock and poultry Heat stress Indices, Agricultural Engineering Technology Guide, Clemson University, Clemson, Sc 29634, USA, using the following formula : $\mathrm{THI}=\mathrm{db}{ }^{\circ} \mathrm{F}-(0.55 \mathrm{RH})\left(\mathrm{db}^{\circ} \mathrm{F}-58.00\right)$ where $\mathrm{db}{ }^{\circ} \mathrm{F}=$ dry bulb temperature in Fahrenheit and $\mathrm{RH}=$ relative humidity $(\mathrm{RH} \%$ $\div 100$ ).. The average values of THI obtained in this experiment were 90.07 (maximum), 71.92 (minimum) during July and 86.39 (maximum), 70.34 (minimum) during August respectively. The obtained values of THI were classified as follows: less than $82=$ absence of heat stress, 82 to $<84=$ moderate heat stress, 84 to $<86=$ severe heat stress and over $86=$ very severe heat stress.

\section{Statistical Analysis:}

Data were subjected to two way analysis of variance using general linear model described in SAS User's Guide (SAS Institute, 1996). Differences among means were tested using Duncan's multiple rang test (Duncan, 1955). Percentages of slaughter traits were divided by 100 and subjected to arc sin transformation of the square root before analysis: however actual percentage means are presented.

\section{RERULTS AND DISCUSSION}

\section{Growth Performance:}

From the data of Table (1), non significant effect of treatments on LBW was noticed 2 wks post starting treatments. However a significant difference $(\mathrm{P} \leq 0.05) \quad$ among treatment groups was detected 2 and 4 wks later, yet the highest $\mathrm{LBW}$ and $\mathrm{BWG}$ were observed by chicks in treatment groups which received ASA at the dosage of $0.5 \mathrm{~g} / \mathrm{kg}$ or AA at 0.5 or $1.0 \mathrm{~g} / \mathrm{kg}$ diet. Moreover, insignificant difference was noted between both the high and low levels of AA. These results are in agreement with those of Kadim et al. (2008) and Roussan et al. (2008). It is known that an ambient temperature of $32-35 \mathrm{C}^{\circ}$ is most appropriate for brooding chicks (Gietema, 1996) and therefore young chicks are more adaptable to high temperature than mature ones (Payne and Wilson, 1999). Apparently, the beneficial effects of AA supplementation would be most expressed under high ambient temperature. Poultry have ability to synthesize ascorbic acid but this ability was inadequate under stress temperature, high humidity, a high productive rate and parasitic infestation (Roussan et al., 2008). 
Table 1. Growth performance of Japanese quail chicks as influenced by supplemental ascorbic acid (AA) or acetylsalicylic acid (ASA) during hot summer season

\begin{tabular}{|c|c|c|c|c|c|c|c|c|}
\hline \multirow{2}{*}{ Variable } & \multirow{2}{*}{$\begin{array}{l}\text { Age } \\
\text { (wk) }\end{array}$} & \multirow{2}{*}{$\begin{array}{c}\text { ASA level (gm/kg } \\
\text { diet) }\end{array}$} & \multicolumn{3}{|c|}{ Vitamin C level (gm/kg diet) } & \multirow{2}{*}{$\begin{array}{l}\text { Overall } \\
\text { Mean }\end{array}$} & \multirow[b]{2}{*}{ SEM } & \multirow{2}{*}{$\begin{array}{c}\text { Sig. } \\
\text { of } \\
\text { inter. }\end{array}$} \\
\hline & & & 0.0 & 0.5 & 1.0 & & & \\
\hline \multirow{3}{*}{$\widehat{\widehat{\overparen{E}}}$} & \multirow{3}{*}{ initial } & 0.0 & 6.95 & 7.05 & 6.89 & 6.96 & & \\
\hline & & 0.50 & 7.11 & 6.91 & 6.93 & 6.98 & 0.07 & NS \\
\hline & & Overall mean & 7.03 & 6.98 & 6.92 & & & \\
\hline 空 & \multirow{3}{*}{2} & 0.0 & 70.06 & 70.48 & 68.70 & 69.75 & & \\
\hline$己$ & & 0.50 & 69.64 & 69.50 & 69.07 & 69.40 & 0.54 & NS \\
\hline$\stackrel{\vec{t}}{2}$ & & Overall mean & 69.85 & 69.99 & 68.88 & & & \\
\hline$\frac{.00}{20}$ & \multirow{3}{*}{4} & 0.0 & 152.18 & 174.39 & 165.61 & $164.06^{\mathrm{B}}$ & & \\
\hline 3 & & 0.50 & 167.35 & 169.84 & 172.80 & $170.00^{\mathrm{A}}$ & 8.08 & $* *$ \\
\hline 永 & & Overall mean & $159.77^{\mathrm{b}}$ & $172.11^{\mathrm{a}}$ & $169.21^{\mathrm{a}}$ & & & \\
\hline$\oplus$ & \multirow{3}{*}{6} & 0.0 & 205.83 & 225.50 & 228.35 & $219.89^{\mathrm{B}}$ & & \\
\hline$\sum_{. \geq}^{\infty}$ & & 0.50 & 214.87 & 237.32 & 231.35 & $227.85^{\mathrm{A}}$ & 3.98 & $*$ \\
\hline • & & Overall mean & $210.35^{\mathrm{b}}$ & $231.41^{\mathrm{a}}$ & $229.85^{\mathrm{a}}$ & & & \\
\hline \multirow{12}{*}{ 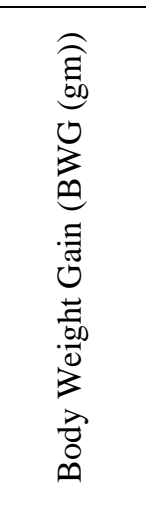 } & \multirow{4}{*}{$0-2$} & 0.0 & 63.10 & 63.43 & 61.81 & 62.77 & & \\
\hline & & 0.50 & 62.54 & 62.59 & 62.15 & 62.42 & 2.12 & NS \\
\hline & & Overall mean & 62.82 & 63.52 & 61.97 & & & \\
\hline & & 0.0 & 82.12 & 103.91 & 96.91 & $94.31^{\mathrm{B}}$ & & \\
\hline & \multirow[t]{2}{*}{$2-4$} & 0.50 & 97.72 & 100.34 & 103.74 & $100.59^{\mathrm{A}}$ & 10.89 & $*$ \\
\hline & & Overall mean & $89.92^{b}$ & $102.12^{\mathrm{a}}$ & $100.32^{\mathrm{a}}$ & & & \\
\hline & \multirow{3}{*}{$2-6$} & 0.0 & 135.76 & 155.01 & 159.65 & $150.14^{\mathrm{B}}$ & & \\
\hline & & 0.50 & 145.24 & 167.82 & 162.29 & $158.45^{\mathrm{A}}$ & 5.63 & $*$ \\
\hline & & Overall mean & $140.50^{\mathrm{b}}$ & $161.42^{\mathrm{a}}$ & $160.97^{\mathrm{a}}$ & & & \\
\hline & \multirow{3}{*}{$0-6$} & 0.0 & 198.88 & 218.45 & 221.46 & $212.93^{\mathrm{B}}$ & & \\
\hline & & 0.50 & 207.76 & 230.41 & 224.42 & $220.86^{\mathrm{A}}$ & 8.43 & $*$ \\
\hline & & Overall mean & $203.32^{\mathrm{b}}$ & $224.43^{\mathrm{a}}$ & $222.94^{\mathrm{a}}$ & & & \\
\hline \multirow{12}{*}{ 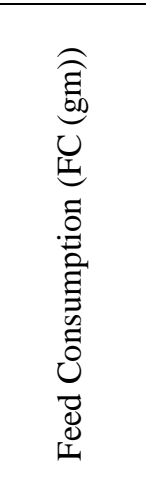 } & \multirow{3}{*}{$0-2$} & 0.0 & 97.65 & 96.43 & 95.66 & 96.58 & & \\
\hline & & 0.50 & 94.88 & 97.43 & 98.11 & 96.80 & 4.47 & NS \\
\hline & & Overall mean & 96.27 & 96.93 & 96.88 & & & \\
\hline & \multirow{3}{*}{$2-4$} & 0.0 & 313.00 & 329.00 & 335.50 & $325.67^{\mathrm{B}}$ & & \\
\hline & & 0.50 & 339.00 & 347.50 & 359.00 & $345.00^{\mathrm{A}}$ & 24.50 & $*$ \\
\hline & & Overall mean & $326.00^{\mathrm{b}}$ & $338.75^{\mathrm{a}}$ & $347.25^{\mathrm{a}}$ & & & \\
\hline & & 0.0 & 637.50 & 640.50 & 648.50 & 641.83 & & \\
\hline & $2-6$ & 0.50 & 648.50 & 655.00 & 655.50 & 652.80 & 47.75 & NS \\
\hline & & Overall mean & 643.00 & 647.50 & 652.00 & & & \\
\hline & & 0.0 & 735.15 & 736.93 & 744.16 & 738.75 & & \\
\hline & $0-6$ & 0.50 & 743.38 & 752.43 & 753.61 & 749.79 & 41.19 & NS \\
\hline & & Overall mean & 739.27 & 744.68 & 748.88 & & & \\
\hline & & 0.0 & 1.55 & 1.52 & 1.55 & 1.54 & & \\
\hline (x) & $0-2$ & 0.50 & 1.52 & 1.56 & 1.58 & 1.55 & 0.002 & NS \\
\hline 迅 & & Overall mean & 1.53 & 1.54 & 1.56 & & & \\
\hline$\stackrel{\circ}{=}$ & & 0.0 & 3.81 & 3.17 & 3.45 & 3.48 & & \\
\hline Еี & $2-4$ & 0.50 & 3.47 & 3.46 & 3.46 & 2.46 & 0.014 & NS \\
\hline 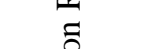 & & Overall mean & $3.64^{\mathrm{a}}$ & $3.31^{\mathrm{b}}$ & $3.45^{\mathrm{b}}$ & & & \\
\hline$\cdot \frac{0}{2}$ & & 0.0 & 4.69 & 4.13 & 4.06 & $4.29^{\mathrm{A}}$ & & \\
\hline $\bar{D}$ & $2-6$ & 0.50 & 4.46 & 3.90 & 4.04 & $4.13^{\mathrm{B}}$ & 0.005 & $*$ \\
\hline ธี & & Overall mean & $4.58^{\mathrm{a}}$ & $4.02^{\mathrm{b}}$ & $4.05^{\mathrm{b}}$ & & & \\
\hline 0 & & 0.0 & 3.69 & 3.37 & 3.36 & 3.48 & & \\
\hline ष्ల & $0-6$ & 0.50 & 3.58 & 3.26 & 3.36 & 3.40 & 0.003 & NS \\
\hline & & Overall mean & $3.64^{\mathrm{a}}$ & $3.32^{\mathrm{b}}$ & $3.36^{\mathrm{b}}$ & & & \\
\hline
\end{tabular}

a-c Means within a column (having capital letters) or a row (having small letters) are significantly different $(\mathrm{P} \leq 0.05) . \mathrm{NS}=$ not significant; $*=(\mathrm{P} \leq 0.05)$.

Concerning feed consumption data, it generally observed that chicks in control group consumed insignificantly less feed during the most experimental period except during the period from 2 to 4 WOA $(\mathrm{P} \leq 0.05)$ when compared with the other groups (Table 1). This 
result supported the recent finding of Ali and Al-Qarawi (2010) and Tuleun et al. (2011) that the addition of antioxidant, AA may scavenge the free radicals generated by high ambient temperature, leading to improved feed consumption. In this connection, Kadim et al. (2008) revealed that under the conditions of heat stress and absence of using anti-stress agents, birds reduce their feed consumption to diminish the thermogenic effect associated with nutrients absorption assimilation and utilization.

Data of cumulative FCR, from 0 to 6 WOA, were significantly improved with supplemental AA comparable to ASA and non supplemented groups (Table 1). Additionally, there was no significant difference between the low and high level of AA. These results agreed with those obtained by Sahin et al. (2003), Lohakare et al. (2005), Kadim et al. (2008) and Roussan et al. (2008). The depression in growth rate and body weight gain at high temperature $\left(30-33{ }^{\circ} \mathrm{C}\right)$ might have been caused by many factors, including decreased feed consumption inefficient digestion, impaired metabolism and genetic background (Tayeb, 2009). In addition, Laura et al. (2009) illustrated that the stress of high ambient temperature can induce an inflammation in the intestine thereby increasing the risk for lower increase in villus/crypt ratio which introduce syndrome of chronic enteritis and can be characterized by decreasing the digestibility which produced low production.

Also, the data in table (1) noticed that AA and ASA interaction was significant for LBW and BWG and not significant for the FC and FCR during the whole experimental period.

It was assumed that improvement in performance data is associated with the suppressed stress responses indicated by the reduction on plasma corticosterone level, adonecorticotropic, and increased serum insulin, $\mathrm{T}_{3}$, and $\mathrm{T}_{4}$ concentration (Mckee and Harrison, 1995 and Lin et al., 2006). Moreover, Sahin et al. (2003) postulated that, through their effect as antioxidants, AA and ASA might have a protective effect on pancreatic tissue against oxidative damage. Consequently, they may help pancreas in secretion of digestive enzymes and insulin (known as an anabolic hormone for amino acids), in consequence improving digestion, absorption, utilization and retention of dietary nitrogen and minerals. Additionally, it is well known that AA improves assimilation by reduction of $\mathrm{Fe}^{+3}$ to $\mathrm{Fe}^{+2}$, which is better assimilated by the intestine, thus enhance resistance to infections. Oxidative lesions are leading to conformational modifications of proteins that could induce pancreatic enzymes inhibition and/or dietary protein resistance to digestion. Thereby, the presence of antioxidant agent like AA could partially interfere with oxidative protein denaturation and can improve digestibility of nutrients and FCR (Pinar, 2008).

On the other hand, the present results are in disagreement with Stillborn et al. (1988) who reported that AA and ASA in the diet at various concentrations were without beneficial effect on broiler growth or feed efficiency. Also, Konka et al. (2008) found that LBW, FC and FCR of the turkeys were not affected by dietary AA during the high summer temperature.

\section{Rectal Temperature (RT) and Respiration Rate (RR):}

The effects of either AA or ASA or both on RT and RR of Japanese quail chicks under the conditions of summer season are presented in Table (2). The results showed a significant reduction in both traits throughout the experimental period due to supplementation of either AA or ASA comparable to the non supplemented control group. The observed effect of dietary AA supplementation are in accordance with those found in turkey (Adenkola and Ayo, 2009); broiler chicks (Tayeb et al., 2011) and in laying hens (Hassan et al. (2011). Yahav et al. (1997) attributed the useful effect of AA on thermoregulation during heat stress to the enhancement of heat dissipation and reducing oxygen utilization. In a similar manner, Kultu and Forbes (1993) reported that heat-stressed birds given AA exhibited relatively less panting than their nonsupplemented counterparts.

Concerning the effect of supplemental ASA, the current results confirmed those found by Abu El-Soud et al. (2006). They indicated that feeding laying Japanese quail on either 500 or 1000 ppm ASA under hot summer season significantly decreased RT. However, McDaniel and Parker (2004) reported that dietary supplementation of ASA failed to decrease the RT of heat stressed roosters. The beneficial effect of ASA in reduction the RT during heat stress could be ascribed to the known action of ASA as antipyretic drug. It could inhibit the prostaglandins synthesis and reset the hypothalamic thermostat. Prostaglandins have been proposed as feasible mediators of the unfavorable effects of high ambient temperature (Weissmann, 1991). Besides, it could be speculated that heat stress episode can lead to generation of free radicals, which are exergonic. They contribute with failure of the thermoregulation process to the increased rectal temperature observed during stress condition of summer season. Thereby, dietary supplementation of these two 
antioxidant agents could attenuate the deleterious oxidative stress.

Table 2. Rectal temperature and respiration rate of Japanese quail chicks as influenced by supplemental ascorbic acid (AA) or acetylsalicylic acid (ASA) during hot summer season

\begin{tabular}{|c|c|c|c|c|c|c|c|c|}
\hline \multirow[b]{2}{*}{ Variable } & \multirow{2}{*}{$\begin{array}{l}\text { Age } \\
\text { (wk) }\end{array}$} & \multirow{2}{*}{$\begin{array}{c}\text { ASA level (gm/kg } \\
\text { diet) }\end{array}$} & \multicolumn{3}{|c|}{ Vitamin C level (gm/kg diet) } & \multirow{2}{*}{$\begin{array}{l}\text { Overall } \\
\text { Mean }\end{array}$} & \multirow[b]{2}{*}{ SEM } & \multirow{2}{*}{$\begin{array}{c}\text { Sig. } \\
\text { of } \\
\text { inter. }\end{array}$} \\
\hline & & & $\mathbf{0 . 0}$ & 0.5 & 1.0 & & & \\
\hline \multirow{9}{*}{ 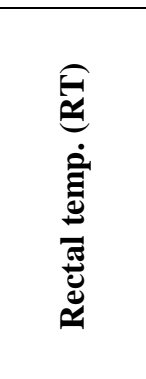 } & \multirow{3}{*}{2} & 0.0 & 42.41 & 40.02 & 40.49 & $41.24^{\mathrm{A}}$ & \multirow{3}{*}{0.52} & \multirow{3}{*}{ NS } \\
\hline & & 0.50 & 41.17 & 40.25 & 40.19 & $40.52^{\mathrm{B}}$ & & \\
\hline & & Overall mean & $41.79^{\mathrm{a}}$ & $40.66^{\mathrm{b}}$ & $40.35^{\mathrm{b}}$ & & & \\
\hline & \multirow{3}{*}{4} & 0.0 & 41.58 & 40.24 & 40.93 & $40.88^{\mathrm{A}}$ & \multirow{3}{*}{0.19} & \multirow{3}{*}{$*$} \\
\hline & & 0.50 & 40.70 & 40.40 & 40.28 & $40.41^{\mathrm{B}}$ & & \\
\hline & & Overall mean & $41.22^{\mathrm{a}}$ & $40.32^{\mathrm{b}}$ & $40.55^{\mathrm{b}}$ & & & \\
\hline & \multirow{3}{*}{6} & 0.0 & 41.98 & 40.93 & 40.41 & $41.06^{\mathrm{A}}$ & \multirow{3}{*}{0.30} & \multirow{3}{*}{$*$} \\
\hline & & 0.50 & 40.60 & 40.18 & 40.76 & $40.48^{\mathrm{B}}$ & & \\
\hline & & Overall mean & $41.24^{\mathrm{a}}$ & $40.56^{\mathrm{b}}$ & $40.57^{\mathrm{b}}$ & & & \\
\hline \multirow{9}{*}{ 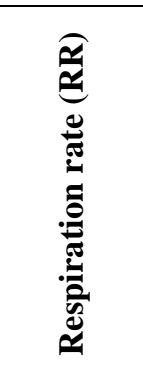 } & \multirow{3}{*}{2} & 0.0 & 104.67 & 84.00 & 80.57 & $89.73^{A}$ & \multirow{3}{*}{5.01} & \multirow{3}{*}{$*$} \\
\hline & & 0.50 & 86.29 & 80.0 & 78.00 & $81.39^{\mathrm{B}}$ & & \\
\hline & & Overall mean & $95.41^{\mathrm{a}}$ & $82.25^{\mathrm{b}}$ & $79.20^{\mathrm{b}}$ & & & \\
\hline & \multirow{3}{*}{4} & 0.0 & 79.14 & 64.67 & 57.71 & $67.30^{\mathrm{A}}$ & \multirow{3}{*}{2.77} & \multirow{3}{*}{$*$} \\
\hline & & 0.50 & 63.60 & 63.14 & 59.71 & $62.00^{\mathrm{B}}$ & & \\
\hline & & Overall mean & $72.67^{\mathrm{a}}$ & $63.85^{\mathrm{b}}$ & $58.71^{\mathrm{b}}$ & & & \\
\hline & \multirow{3}{*}{6} & 0.0 & 80.57 & 56.57 & 56.00 & $64.8^{\mathrm{A}}$ & \multirow{3}{*}{3.04} & \multirow{3}{*}{$*$} \\
\hline & & 0.50 & 63.33 & 56.57 & 62.67 & $60.63^{\mathrm{B}}$ & & \\
\hline & & Overall mean & $72.11^{\mathrm{a}}$ & $56.57^{\mathrm{b}}$ & $59.33^{\mathrm{b}}$ & & & \\
\hline
\end{tabular}

a-c Means within a column (having capital letters) or a row (having small letters) are significantly different $(\mathrm{P} \leq 0.05)$. NS= not significant; $*=(\mathrm{P} \leq 0.05)$.

The interaction between the AA and ASA respecting the RT and RR was significant for RT at 4 and 6 wks post treatment, and at all estimated ages for RR. These might indicate the magnitude of their effects in improving the hypothalamic thermoregulation of Japanese quail chicks during hot summer condition.

\section{Serum Metabolites and Lipid Peroxidation:}

It is clearly shown from Table (3) that serum level of both total protein and albumin were significantly increased in control group, due to the stress of hot summer, when compared with those of either ASA or AA groups at high and low levels. Similar trend, however insignificant, was found for the serum globulin concentration and the albumin $/$ globulin $(\mathrm{A} / \mathrm{G})$ ratio. The elevation in the serum proteins and its fractions in the control chicks may be attributed to increased protein catabolism associated with corticosteroid release. Whereas, the lower values observed for the supplemented groups may be due to lower corticosteroids levels and therefore a reduction in protein-derived gluconeogenesis (Pardue et al., 1985). Also, Yahav et al. (1997) reported that high ambient temperature resulted in blood hypervolemia to provide the fluid needed for heat dissipation by panting. This hypervolemia may be referred to considerable increase in total blood proteins. It is note worth that, albumin/globulin (A/G) ratio has been well known as an indicator for the metabolic activities and immune resistance. AS well as, the low $\mathrm{A} / \mathrm{G}$ ratio indicates more disease resistance and immune response (Griminger, 1986). This might indicate better immunity and disease resistance for the chicks of ASA or AA compared to those of control group. In accordance with the present finding, Bealish (2011) pointed out that serum blood globulin in male Japanese quails was increased due to supplemental AA at the dosage of $0.08 \%$ indicating that this may has a benefit in diseases resistance.

Data presented in Table (3) showed a significant reduction in serum concentration of glucose, total lipids, cholesterol and the activity of malondialdehyde (MDA) in chicks received either ASA or AA during summer season comparable to chicks of control basal diet. Moreover, insignificant difference was found between the high and low level of AA. The observed reduction in serum glucose is in agreement with the results of Mohammed (2010) who found a negative linear relationship between the blood concentration of glucose and drinking water level of ASA. Also, Tayeb et al. (2011) showed that glucose was significantly highest in broiler control groups with no AA supplement compared with the supplemented ones. In a similar trend, Sahin et al. (2002) and Abou El-Soud et al. (2006) fed Japanese quail chicks and hens on 
diets provided with AA and ASA, respectively. They reported that AA and ASA treatment caused a significant reduction in serum glucose and cholesterol. However, the results of Mehmet (2005) and Usman et al. (2008) contradicted with the present findings. The effect of ASA and AA on both hypocholesteremia and hypoglycemia during thermal stress could be attributed to their action in reducing the secretion and/or synthesis of glucocorticoids as well as, mobilization of cholesterol from peripheral tissues (Kultu and Forbes, 1993 and Abou ElSoud et al., 2006). Sahin et al. (2003 a,b) illustrated that during periods of heat stress, increasing concentrations of corticosterone was paralleled to increases in serum glucose and cholesterol concentrations. This was probably due to the greater catabolic effect of corticosterone.

Table 3. Serum metabolites and lipid peroxidation of Japanese quail chicks as influenced by supplemental ascorbic acid (AA) or acetylsalicylic acid (ASA) during hot summer season

\begin{tabular}{|c|c|c|c|c|c|c|c|}
\hline \multirow{2}{*}{ Variable } & \multirow{2}{*}{$\begin{array}{c}\text { ASA level } \\
\text { (gm/kg diet) }\end{array}$} & \multicolumn{3}{|c|}{ Vitamin C level (gm/kg diet) } & \multirow{2}{*}{$\begin{array}{l}\text { Overall } \\
\text { mean }\end{array}$} & \multirow{2}{*}{ SEM } & \multirow{2}{*}{$\begin{array}{c}\text { Sig. } \\
\text { of } \\
\text { inter. }\end{array}$} \\
\hline & & $\mathbf{0 . 0}$ & 0.5 & 1.0 & & & \\
\hline \multirow{3}{*}{$\begin{array}{l}\text { Total protein } \\
\quad(\mathrm{g} / \mathrm{dL})\end{array}$} & 0.0 & 4.50 & 4.35 & 4.39 & $4.413^{\mathrm{A}}$ & & \\
\hline & 0.50 & 3.90 & 3.71 & 3.77 & $3.793^{\mathrm{B}}$ & 0.07 & NS \\
\hline & Overall mean & $4.20^{\mathrm{a}}$ & $4.03^{b}$ & $4.08^{\mathrm{b}}$ & & & \\
\hline \multirow{3}{*}{$\begin{array}{l}\text { Albumin (A) } \\
\quad(g / d L)\end{array}$} & 0.0 & 2.29 & 2.11 & 2.13 & $2.176^{\mathrm{A}}$ & & \\
\hline & 0.50 & 1.88 & 1.80 & 1.82 & $1.833^{\mathrm{B}}$ & 0.01 & NS \\
\hline & Overall mean & $2.085^{\mathrm{a}}$ & $1.955^{\mathrm{b}}$ & $1.975^{\mathrm{b}}$ & & & \\
\hline \multirow{4}{*}{$\begin{array}{l}\text { Globulin }(\mathbf{G}) \\
\quad(\mathrm{g} / \mathrm{dL})\end{array}$} & 0.0 & 2.21 & 2.24 & 2.26 & $2.236^{\mathrm{A}}$ & & \\
\hline & 0.50 & 2.02 & 1.91 & 1.95 & $1.96^{\mathrm{B}}$ & 0.05 & NS \\
\hline & Overall mean & 2.115 & 2.075 & 2.105 & & & \\
\hline & 0.0 & 1.036 & 0.942 & 0.942 & 0.973 & & \\
\hline \multirow[t]{3}{*}{ A/G ratio } & 0.50 & 0.93 & 0.942 & 0.933 & 0.933 & 0.01 & NS \\
\hline & Overall mean & 0.985 & 0.942 & 0.938 & & & \\
\hline & 0.0 & 254.68 & 237.10 & 233.67 & $242.62^{\mathrm{A}}$ & & \\
\hline \multirow[t]{2}{*}{ Glucose (mg/dL) } & 0.50 & 233.75 & 238.96 & 228.74 & $233.52^{\mathrm{B}}$ & 9.91 & * \\
\hline & Overall mean & $244.22^{\mathrm{a}}$ & $238.03^{\mathrm{ab}}$ & $230.98^{\mathrm{b}}$ & & & \\
\hline \multirow{3}{*}{$\begin{array}{l}\text { Total lipid } \\
\text { (mg/dL) }\end{array}$} & 0.0 & 1466.50 & 1178.58 & 1089.22 & $1258.63^{\mathrm{A}}$ & & \\
\hline & 0.50 & 1269.85 & 1115.60 & 1148.50 & $1181.65^{\mathrm{B}}$ & 26.50 & $*$ \\
\hline & Overall mean & $1368.18^{\mathrm{a}}$ & $1147.09^{\mathrm{b}}$ & $1121.56^{\mathrm{b}}$ & & & \\
\hline \multirow{3}{*}{$\begin{array}{c}\text { Cholesterol } \\
(\mathrm{mg} / \mathrm{dL})\end{array}$} & 0.0 & 421.56 & 352.17 & 326.99 & $366.91^{\mathrm{A}}$ & & \\
\hline & 0.50 & 295.31 & 277.04 & 270.51 & $280.95^{\mathrm{B}}$ & 29.94 & * \\
\hline & Overall mean & $358.43^{\mathrm{a}}$ & $314.61^{\mathrm{b}}$ & $296.19^{b}$ & & & \\
\hline Malondialdehyde & 0.0 & 0.210 & 0.182 & 0.160 & $0.182^{\mathrm{A}}$ & & \\
\hline (MDA) (535nm) & 0.50 & 0.192 & 0.175 & 0.164 & $0.175^{\mathrm{B}}$ & 0.0002 & $*$ \\
\hline $\mathrm{nmol} / \mathrm{mL}$ & Overall mean & $0.202^{\mathrm{a}}$ & $0.179^{\mathrm{b}}$ & $0.162^{\mathrm{c}}$ & & & \\
\hline
\end{tabular}

${ }^{\mathrm{a}-\mathrm{c}}$ Means within a column (having capital letters) or a row (having small letters) are significantly different $(\mathrm{P} \leq 0.05) . \mathrm{NS}=$ not significant. $*=(\mathrm{P} \leq 0.05)$.

The interaction between AA and ASA was significant for serum levels of glucose, cholesterol, total lipid and MDA, but insignificant for total protein and its fraction.

It is known that heat stress induces oxidative damage through producing free radicals such as $\mathrm{O}$ and $\mathrm{OH}$ that caused proinflammatory cytokines, IL-1, IL-6 and TNF- $\alpha$ (Kanazawa, 2007). This is leading to death due to heart failure and blood circulation dysfunction (Vila et al., 2007). As well as, these free radicals can damage cell membranes by inducing lipid per oxidation of polyunsaturated fatty acids in the cell membrane. Moreover, the oxidative damage of proteins can result in reducing the biological functions and enhanced susceptibility to proteolysis (Abou El-Soud et al., 2006). It is observable that supplemental ASA and/or AA decreased, in a dose dependent manner, the level of MDA which is considered as an indicator for oxidative stress,. This reduction could be related to adjusting the levels of corticosterone and $\mathrm{T}_{3}$. Taniguchi et al. (1999) showed that corticosterone induced elevation of blood MDA in broiler. Furthermore, Ipek et al. (2007) reported that vitamin $\mathrm{C}$ is considered as a primary antioxidant in the biological systems and break the chain of lipid per oxidation in cell membranes.

\section{Liver, Kidney and Thyroid Functions:}

Results in Table (4) indicated that adding of either AA or ASA significantly reduced the liver enzyme activities (AST and ALT) compared with the non supplemented control 
group. Since the elevation of both enzymes is considered as a sensitive index of hepatic dysfunction. The present result may reflect liver disturbances of control group. Therefore the results indicated that supplemental of AA and/or ASA could protect the liver tissues from being destroyed in response to heat stress of summer season. In accordance with our this finding, Khan and Sardar (2005) showed that activities of blood enzymes (ALT, AST) in groups layers supplemented with vitamin C was lower $(\mathrm{P} \leq 0.01)$ than those of groups without. According to Bhatti et al. (2003) and Bhatti and Dil (2005) alteration in serum enzymes activity under stress conditions occur due to malfunctioning of liver, as degenerating and necrotic cells leak enzymes from cytoplasm.

Table 4. Liver, kidney and thyroid gland activities of Japanese quail chicks as influenced by supplemental ascorbic acid (AA) or acetylsalicylic acid (ASA) during hot summer season

\begin{tabular}{|c|c|c|c|c|c|c|c|}
\hline \multirow{2}{*}{ Variable } & \multirow{2}{*}{$\begin{array}{c}\text { ASA level } \\
\text { (gm/kg diet) }\end{array}$} & \multicolumn{3}{|c|}{ Vitamin C level (gm/kg diet) } & \multirow{2}{*}{$\begin{array}{c}\text { Overall } \\
\text { mean }\end{array}$} & \multirow{2}{*}{ SEM } & \multirow{2}{*}{$\begin{array}{l}\text { Sig. of } \\
\text { inter. }\end{array}$} \\
\hline & & 0.0 & 0.5 & 1.0 & & & \\
\hline \multirow{3}{*}{ AST (U/I) } & 0.0 & 120.03 & 88.49 & 90.00 & 100.79 & & \\
\hline & 0.50 & 103.27 & 92.12 & 96.08 & 97.45 & 33.97 & $*$ \\
\hline & Overall mean & $111.65^{\mathrm{a}}$ & $90.30^{\mathrm{b}}$ & $93.32^{\mathrm{b}}$ & & & \\
\hline \multirow{3}{*}{ ALT (U/I) } & 0.0 & 22.93 & 18.80 & 19.14 & 20.45 & & \\
\hline & 0.50 & 22.63 & 18.43 & 18.72 & 20.01 & 3.48 & NS \\
\hline & Overall mean & $22.78^{\mathrm{a}}$ & $18.61^{\mathrm{b}}$ & $18.91^{\mathrm{b}}$ & & & \\
\hline \multirow{3}{*}{$\begin{array}{l}\text { Uric acid } \\
(\mathbf{m g} / \mathbf{d L})\end{array}$} & 0.0 & 2.88 & 2.48 & 2.39 & $2.62^{\mathrm{A}}$ & & \\
\hline & 0.50 & 2.70 & 2.10 & 2.11 & $2.30^{\mathrm{B}}$ & 0.05 & NS \\
\hline & Overall mean & $2.80^{\mathrm{a}}$ & $2.28^{\mathrm{b}}$ & $2.24^{\mathrm{b}}$ & & & \\
\hline \multirow{3}{*}{$\begin{array}{c}\text { Creatinine } \\
\text { (mg/dL) }\end{array}$} & 0.0 & 2.01 & 1.90 & 1.83 & 1.93 & & \\
\hline & 0.50 & 1.97 & 1.87 & 1.90 & 1.91 & 0.02 & NS \\
\hline & Overall mean & 1.99 & 1.88 & 1.87 & & & \\
\hline \multirow{4}{*}{$\mathrm{T}_{3}(\mathrm{ng} / \mathrm{ml})$} & 0.0 & 3.29 & 3.98 & 4.23 & $3.84^{\mathrm{B}}$ & & \\
\hline & 0.50 & 3.54 & 4.15 & 4.75 & $4.15^{\mathrm{A}}$ & 0.05 & NS \\
\hline & Overall mean & $3.42^{\mathrm{c}}$ & $4.07^{\mathrm{b}}$ & $4.49^{\mathrm{a}}$ & & & \\
\hline & 0.0 & 13.32 & 14.73 & 16.30 & $14.78^{\mathrm{B}}$ & & \\
\hline \multirow[t]{3}{*}{$\mathrm{T}_{4}(\mathrm{ng} / \mathrm{ml})$} & 0.50 & 13.99 & 15.56 & 17.08 & $15.54^{\mathrm{A}}$ & 0.38 & NS \\
\hline & Overall mean & $13.65^{\mathrm{c}}$ & $15.15^{\mathrm{b}}$ & $16.69^{\mathrm{a}}$ & & & \\
\hline & 0.0 & 0.25 & 0.27 & 0.26 & 0.26 & & \\
\hline \multirow[t]{2}{*}{$\mathbf{T}_{3} / \mathbf{T}_{4}$ ratio } & 0.50 & 0.25 & 0.27 & 0.28 & 0.27 & 0.002 & NS \\
\hline & Overall mean & $0.25^{\mathrm{b}}$ & $0.27^{\mathrm{a}}$ & $0.27^{\mathrm{a}}$ & & & \\
\hline
\end{tabular}

${ }^{\mathrm{a}-\mathrm{c}}$ Means within a column (having capital letters) or a row (having small letters) are significantly different $(\mathrm{P} \leq 0.05)$. NS= not significant.

Kidney functions were expressed by the level of uric acid and creatinine as shown in Table (4). The birds supplemented with 0.5 $\mathrm{g} / \mathrm{kg}$ diet ASA, 0.5 or $1 \mathrm{~g} / \mathrm{kg}$ AA, had significantly and insignificantly lower serum level of uric acid and creatinine than control group, respectively. Thus, supplemental either AA or ASA might improve the utilization of dietary protein metabolism. Goldstein and Skadhauge (2000) stated that the end products of nitrogen metabolism excreted in the urine of birds include urates, ammonia, urea, creatinine, amino acids, and others.

Results in Table (4) indicated that supplementation diet with AA or ASA had significantly increased serum concentration of thyroid gland hormones $\left(\mathrm{T}_{3}\right.$ and $\left.\mathrm{T}_{4}\right)$ and the their conversion ratio $\left(\mathrm{T}_{3} \backslash \mathrm{T}_{4}\right.$ ratio) comparable to the control group which was significantly $(\mathrm{P} \leq 0.05)$ the lowest among the whole experimental treatments. Thyroid gland is important in heat stress adaptation through its crucial role in regulating the metabolic role. In partial agreement with this result, Hassan et al. (2011) found that AA significantly increased $\mathrm{T}_{4}$ but did not influence the level of $\mathrm{T}_{3}$ hormone. However, Abou El-Soud et al. (2006) showed that dietary ASA reduced serum concentration of $\mathrm{T}_{3}$ in laying Japanese quails reared under hot summer condition. The present results indicated that through their role in reducing the corticosterone level the ASA and/or AA have the potential for overcoming the detrimental effects of heat stress in growing Japanese quail. Durgan and Keksin (1998) reported a negative relationship between corticosterone and $\mathrm{T}_{3}$ concentrations during heat stress episode.

\section{Humeral Immunity against Avian Newcastle Disease Virus (NDV):}

Antibody titers against avian Newcastle disease virus (NDV) with using AA and ASA are shown in table (5). When compared with 
control, seven day post-primary NDV immunization, the all supplemented groups had numerically higher total, $\operatorname{IgM}$ and $\operatorname{IgG}$ anti NDV antibodies but the results were not significant. Concerning antibody production levels determined seven $d$ post-second challenge with (NDV) the obtained results showed that, birds with no supplement had significantly $(\mathrm{P} \leq 0.05)$ the lowest total and $\mathrm{IgG}$ anti NDV antibodies when compared with those given ASA or AA at any level. It is suggested that supplementation of AA and/or ASA could promote the bird competency during periods of stress, reducing the adverse effects of stress and enhancing recovery from stressful periods.

Table 5. Antibody titers against NDV of Japanese quail chicks as influenced by supplemental ascorbic acid (AA) or acetylsalicylic acid (ASA) during hot summer season

\begin{tabular}{|c|c|c|c|c|c|c|c|c|}
\hline \multirow{2}{*}{ Variable } & \multirow{2}{*}{ Ig } & \multirow{2}{*}{$\begin{array}{l}\text { ASA level } \\
\text { (gm/kg diet) }\end{array}$} & \multicolumn{3}{|c|}{ Vitamin C level (gm/kg diet) } & \multirow{2}{*}{$\begin{array}{l}\text { Overall } \\
\text { mean }\end{array}$} & \multirow{2}{*}{ SEM } & \multirow{2}{*}{$\begin{array}{l}\text { Sig. of } \\
\text { inter. }\end{array}$} \\
\hline & & & $\mathbf{0 . 0}$ & 0.5 & 1.0 & & & \\
\hline \multirow{10}{*}{ 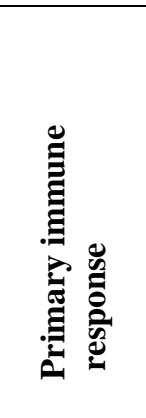 } & \multirow{3}{*}{ Total } & 0.0 & 3.91 & 4.22 & 4.44 & 4.17 & & \\
\hline & & 0.50 & 4.38 & 4.44 & 4.33 & 4.38 & 0.26 & NS \\
\hline & & Overall mean & 4.11 & 4.33 & 4.39 & & & \\
\hline & \multirow{3}{*}{$\operatorname{IgM}$} & 0.0 & 2.73 & 3.22 & 3.33 & 3.07 & & \\
\hline & & 0.50 & 3.25 & 3.44 & 3.33 & 3.35 & 0.31 & NS \\
\hline & & Overall mean & 2.95 & 3.33 & 3.33 & & & \\
\hline & \multirow{4}{*}{$\operatorname{IgG}$} & 0.0 & 1.18 & 1.00 & 1.11 & 1.10 & & \\
\hline & & 0.50 & 1.13 & 1.00 & 1.00 & 1.03 & 0.55 & NS \\
\hline & & Overall mean & 1.15 & 1.00 & 1.05 & & & \\
\hline & & 0.0 & 4.64 & 6.11 & 6.78 & $5.76^{\mathrm{B}}$ & & \\
\hline \multirow{8}{*}{ 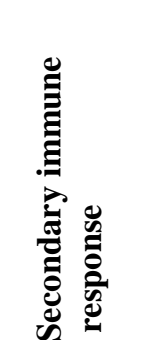 } & \multirow[t]{3}{*}{ Total } & 0.50 & 6.50 & 6.67 & 7.00 & $6.73^{\mathrm{A}}$ & 0.46 & $*$ \\
\hline & & Overall mean & $5.42^{c}$ & $6.39^{\mathrm{b}}$ & $6.89^{\mathrm{a}}$ & & & \\
\hline & & 0.0 & 1.27 & 1.22 & 1.33 & 1.28 & & \\
\hline & \multirow[t]{3}{*}{$\operatorname{IgM}$} & 0.50 & 1.38 & 1.33 & 1.56 & 1.42 & 0.24 & $*$ \\
\hline & & Overall mean & 1.32 & 1.28 & 1.44 & & & \\
\hline & & 0.0 & 3.36 & 4.89 & 5.44 & $4.48^{\mathrm{B}}$ & & \\
\hline & \multirow[t]{2}{*}{$\operatorname{IgG}$} & 0.50 & 5.13 & 5.33 & 5.44 & $5.31^{\mathrm{A}}$ & 0.50 & NS \\
\hline & & Overall mean & $4.11^{\mathrm{b}}$ & $5.11^{\mathrm{a}}$ & $5.44^{\mathrm{a}}$ & & & \\
\hline
\end{tabular}

a-c Means within a column (having capital letters) or a row (having small letters) are significantly different $(\mathrm{P} \leq 0.05)$. NS= not significant; $*=(\mathrm{P} \leq 0.05)$.

The current results are in harmony with Naseem et al. (2005) who used commercial mixture of AA plus ASA had achieved better antibody titer of broiler chicks kept under elevated temperature (34-3 EC). Also the enhancement in the antibody production during heat stress using AA and/or ASA agrees with those of Tayeb (2009) and Hassan et al. (2011) who showed that the supplementation of AA led to increase the immunity and thermotolerance response of heat stressed birds. Several explanations were suggested for the obtained positive correlation between the immune response and the addition of AA and lor ASA. Several explanations were suggested for the obtained positive correlation between the immune response and the addition of AA and/or ASA during periods of heat stress exposure. First, it may be due to their antioxidant properties. They could help to protect immature lymphocytes from being damaged by free radicals due to oxidation (Amakye-Anim et al., 2000). Confirming to this suggestion is the current finding of MDA data (Table 5). Second, as a result of avoiding the detrimental effects of heat stress with supplemental AA and/or ASA, the T-cells increased the production of lymphokines such as interleukin-2 (IL-2), since IL-2 functions are known to stimulate lymphocyte proliferation and induce interferon- $\gamma$ (INF- $\gamma$ ) (Schwagar and Schulze, 1998; Puthpongsiriporn et al., 2001). Third, the immunosuppressive effect of stress is thought to be mediated through the cytotoxic effect of adrenal steroids (Siegel, 1980). Controlling the rate of corticosterone release through inhibition of the 21-hydroxylase and $11 \beta$ - hydroxylase enzymes in the steroid biosynthetic pathway in the adrenal cortex was preferred in coping with stress (Gross, 1988). This might be achieved in the present study by the dietary AA and/or ASA. Fourth, the neuroendocrine-immune interactions may alter the immune response during thermal stress since, heat stress has been found to be linked with the increased plasma corticosterone level resulting in excess catabolism and decreased T3 concentration (Durgan and Keksin, 1998). Moreover, the reduction in the blood $\mathrm{T}_{3}$ level resulted in a decreased antibody response (Marsh and Scanes, 1994). Hence, through their effects in reducing thermal stress, AA 
and/or ASA appear to improve the immune response of growing Japanese quail.

\section{Relative Weights of Lymphoid Organs:}

From Table (6) it is clearly observed that supplementation of AA improved the immune status as reflected by the relative weights of lymphoid organs, which reflect the body's ability to afford lymphoid cells during an immune response. Significant differences were noted among the supplemented groups and the non supplemented one for the relative thymus, spleen and bursa weights. In which, the lowest values were achieved for the group of AA free diet. These results are in full agreement with those of Bashir et al. (1998) who reported that supplementation of AA increased the weight of bursa, thymus and spleen. As well, Naseem et al. (2005) showed that, bursa, thymus and spleen of heat stressed birds were atrophied but those of AA supplemented birds were not.
Supplemental the antioxidant, AA might protect the lymphoid tissues from being damaged by the action of corticosterone produced under conditions of heat stress (Whitehead and Keller, 2003). Furthermore, it may be suggested that the interactions between endocrine and immune systems may be the reason for the observed hypertrophy of the lymphoid organs. Dietary provision of ASA had no significant effect whatsoever on the relative weights of any of the measured lymphoid organs under conditions of the current study. The significant interaction of AA by the ASA for the relative weights of spleen and bursa but not for thymus may indicate the magnitude of their effects, when used in combination, in enhancing the immune response and infectious resistance of quail grown during the hot summer season.

Table 6. Lymphoid Organ relative weight of Japanese quail chicks as influenced by supplemental ascorbic acid (AA) or acetylsalicylic acid (ASA) during hot summer season

\begin{tabular}{|c|c|c|c|c|c|c|c|}
\hline \multirow{2}{*}{ Variable } & \multirow{2}{*}{$\begin{array}{l}\text { ASA level } \\
\text { (gm/kg diet) }\end{array}$} & \multicolumn{3}{|c|}{ Vitamin C level (gm/kg diet) } & \multirow{2}{*}{$\begin{array}{l}\text { Overall } \\
\text { mean }\end{array}$} & \multirow{2}{*}{ SEM } & \multirow{2}{*}{$\begin{array}{l}\text { Sig. } \\
\text { of } \\
\text { inter. }\end{array}$} \\
\hline & & 0.0 & 0.5 & 1.0 & & & \\
\hline \multirow{3}{*}{ Thymus } & 0.0 & 0.051 & 0.061 & 0.063 & 0.058 & & \\
\hline & 0.50 & 0.057 & 0.059 & 0.064 & 0.060 & 0.005 & NS \\
\hline & Overall mean & $0.054^{\mathrm{b}}$ & $0.060^{\mathrm{a}}$ & $0.064^{\mathrm{a}}$ & & & \\
\hline \multirow{3}{*}{ Spleen } & 0.0 & 0.054 & 0.07 & 0.066 & 0.063 & & \\
\hline & 0.50 & 0.059 & 0.059 & 0.061 & 0.060 & 0.003 & $*$ \\
\hline & Overall mean & $0.057^{\mathrm{b}}$ & $0.065^{\mathrm{a}}$ & $0.064^{\mathrm{a}}$ & & & \\
\hline \multirow{3}{*}{ Bursa } & 0.0 & 0.079 & 0.097 & 0.116 & 0.098 & & \\
\hline & 0.50 & 0.090 & 0.096 & 0.109 & 0.099 & 0.007 & $*$ \\
\hline & Overall mean & $0.084^{\mathrm{c}}$ & $0.097^{\mathrm{b}}$ & $0.0112^{\mathrm{a}}$ & & & \\
\hline
\end{tabular}

a-c Means within a column (having capital letters) or a row (having small letters) are significantly different $(\mathrm{p} \leq 0.05)$. NS $=$ not significant. $*=(\mathrm{P} \leq 0.05)$.

\section{Reproductive Organs and The Age at $1^{\text {st }}$ Egg:}

Regarding the effect of supplemental AA and/or ASA on the relative weights of reproductive organs and the age at $1^{\text {st }}$ egg, data presented in Table (7) showed that there was a significant linear relationship between the added dosage of either AA or ASA and the relative weights of testis, ovary and oviduct. Similar trend was achieved for the age at $1^{\text {st }}$ egg, in which the supplemented groups reached to the sexual maturity earlier than the non supplemented one. Further, insignificant difference was noted between the high and low level of AA. These results may put forward prediction toward the improvement of most reproductive traits, particularly egg production and semen quality, for supplemented female and male quails under the high ambient conditions. These results appear to be due to an inverse relationship between plasma concentrations of corticosterone and LHRH in the hypothalamus, resulting in reduced $\mathrm{LH}$ release from quail pituitary cells (Abou ElSoud et al., 2006). Furthermore, glucocorticoids markedly decreased the plasma inhibin concentration which is involved in the regulation of follicular development through FSH secretion. Thereby, it could be suggested that reducing corticosterone level via provision of either AA and/or ASA could induce LH and FSH secretion which consequently activate ovaries and testes development.

It could be concluded that, addition of either ASA or AA at the dosage of $0.5 \mathrm{~g} / \mathrm{kg}$ diet is practically effective in ameliorating the deleterious effects of hot summer and enhancing the general performance, immunity and physiological homeostasis of Japanese quail during the grower period. 
Table 7. Relative reproductive organs and age at 1st egg of Japanese quail chicks as influenced by supplemental ascorbic acid (AA) or acetylsalicylic acid (ASA) during hot summer season

\begin{tabular}{|c|c|c|c|c|c|c|c|}
\hline \multirow{2}{*}{ Variable } & \multirow{2}{*}{$\begin{array}{l}\text { ASA level } \\
\text { (gm/kg diet) }\end{array}$} & \multicolumn{3}{|c|}{ Vitamin C level (gm/kg diet) } & \multirow{2}{*}{$\begin{array}{l}\text { Overall } \\
\text { mean }\end{array}$} & \multirow{2}{*}{ SEM } & \multirow{2}{*}{$\begin{array}{l}\text { Sig. of } \\
\text { inter. }\end{array}$} \\
\hline & & 0.0 & 0.5 & 1.0 & & & \\
\hline \multirow{3}{*}{ Testis } & 0.0 & 1.57 & 2.54 & 3.07 & $2.39^{\mathrm{B}}$ & & \\
\hline & 0.50 & 1.80 & 2.75 & 3.16 & $2.57^{\mathrm{A}}$ & 0.006 & * \\
\hline & Overall mean & $1.68^{\mathrm{c}}$ & $2.65^{\mathrm{b}}$ & 3.11 ${ }^{\mathrm{a}}$ & & & \\
\hline \multirow{3}{*}{ Ovary } & 0.0 & 1.63 & 3.55 & 4.23 & 3.14 & & \\
\hline & 0.50 & 1.94 & 3.63 & 4.27 & 3.27 & 0.061 & * \\
\hline & Overall mean & $1.79^{\mathrm{c}}$ & $3.59^{\mathrm{b}}$ & $4.25 \mathrm{a}$ & & & \\
\hline \multirow{3}{*}{ Oviduct } & 0.0 & 0.94 & 3.93 & 4.76 & $3.21^{\mathrm{B}}$ & & \\
\hline & 0.50 & 2.99 & 3.38 & 4.06 & $3.48^{\mathrm{A}}$ & 0.013 & * \\
\hline & Overall mean & $1.97^{\mathrm{c}}$ & $3.65^{b}$ & 4.41a & & & \\
\hline \multirow{3}{*}{$\begin{array}{l}\text { Age at 1st } \\
\text { egg }\end{array}$} & 0.0 & 46.00 & 43.21 & 42.77 & $43.95^{A}$ & & \\
\hline & 0.50 & 43.08 & 40.49 & 39.89 & $41.22^{B}$ & 2.31 & NS \\
\hline & Overall mean & $44.59^{\mathrm{a}}$ & $41.85^{b}$ & $41.33^{b}$ & & & \\
\hline
\end{tabular}

a-c Means within a column (having capital letters) or a row (having small letters) are significantly different $(\mathrm{P} \leq 0.05)$. NS $=$ not significant.

\section{REFERANCES}

Abou El-Soud, B. Sabriea, T.A. Ebeid and Y.Z. Eid, 2006. Physiological and antioxidative effects of dietary acetyl sakicylic acid in laying Japanese quail (coturnix japonica) under high ambient temperature. Journal of Poultry Science, 43: $255-265$.

Aengwanich, W., 2007. Effects of high environmental temperature on the productive performance of thaiindigenous, thai indigenous crossbred and broiler chickens. International Journal of Poultry Science, 6: 349-353.

Ali, B.H. and A. Al-Qarawi, 2010. An evaluation of drugs used in the control of stressful stimuli in domestic animals: a review. Acta Veterinary Brno, 71:205-216.

Amakye-Anim, J., T.L. Lin, P.Y. Hester, D. Thiagarajan, B.A. Wakins and C.C. Wu, 2000. Ascorbic acid supplementation improved antibody response to infectious bursal disease vaccination in chickens. Poultry Science, 79:680-688.

Bashir, I.N., M.A. Muneer, M.A. Saeed, A. Raza and F.K. Raza, 1998. Immunomodulatry effects of water soluble vitamins on heat stressed broiler chickens. Indian Journal of Animal Nutrition, 15: 1117.

Bealish, A.M.A., 2011. Influence of supplementing acetyl salicylic acid in the diets on laying Japanese quail performance the diets on laying Japanese quail performance reared in hot climate conditions. Egyptian Poultry Science, 31 : 783-792.

Bhatti, B. M., R. Sardar, B. Siddique and T. Talat, 2003. Effect on serum enzyme concentrations and bilirubin in chicken exposed to hydropericardium virus.
Pakistan Journal of Veterinary Research, 1:17-19.

Bhatti, B. M. and S. Dil, 2005. Effect of vitamin $\mathrm{C}$ on immune response in Desi chicken against Newcastle disease. Pakistan Journal of Veterinary Res., 2(1): 48-49.

Dix, M. C. and Jr. R. L. Taylor, 1996. Differential antibody response in 6.B major histocompatibility (B) complex congenic chickens. Poultry Science, 75:203-207.

Duncan, D. B., 1955. Multiple range and multiple F-Test, Biometrics, 11:1-42.

Durgan, Z. and E. Keskin, 1998. The changes associated with fasting and acute heat stress on body temperature, blood acid-base balance and some parameters of Japanese quail. Indian Veterinary Journal, 75:299303.

Etches, R. J., T.M. John and A.M. Verinder Gibbins, 1995. Behavioral physiological, neuroendocrine and molecular response to heat stress. Poultry production in hot climates. Book-Chapter 3. Pp. 31-53.

Gietema, B., 1996. Chicken farming Book 1, Chapter 4: Management of chicken flocks, STOAS Publisher, Wageningen City, Netherland, PP: 35-50.

Goldstein, D.L. and E. Skadhauge, 2000. Renal and extrarenal regulation of body fluid composition. In: Sturkie's avian physiology. Ch. 11. Ed Whittow GC. Academic Press, San Diego.

Griminger. P., 1986. Lipid Metabolism in "AVAIN PHYSIOLOGY" edited by P.D Sturkie.4th edition Springer-Verlag, Inc., New York.

Gross, W.B., 1988. Effect of ascorbic acid on antibody response of stressed and unstressed chickens. Avian Diseases, 32: 483-485. 
Hassan, M.S.H., S. F. Youssef and Nadia. M. A. El-Bahy, 2011. Effect of L-carnitine and ascorbic acid supplementation on productive, physiological and immunological performance of golden Montazah laying hens. Egyptian Poultry Science, 31: 557-578.

Hassan, S. M., M. E. Mady, A.L. Cartwright, H.M. Sabri, and M.S. Mobarak, 2003. Effect of acetyl salicylic acid in drinking water on reproductive performance of Japanese quail (Coturnix coturnix japonica). Poultry Science, 82:1174-1180.

Hitchner, S. B., C. H. Domrmuth, H. G. Purchase, and J. E. Williams, 1980. Isolation and Identification of avian pathologists. Creative printing company Inc. Endwell. New York.

Ipek A., O. Canbolat and A. Karabulut, 2007. The effect of vitamin e and vitamin $\mathrm{c}$ on the performance of japanese quails (Coturnix coturnix japonica) reared under heat stress during growth and egg production period. Asian-Aust. Journal of Animal Science, 20: $252-256$.

Kadim, I. T., B.H.A. Al-Qamshui, O. Mahgoub, W. Al-Marzooqi and E.H. Johnson, 2008. Effect of Seasonal temperatures and Ascorbic Acid supplementation on performance of Broiler Chickens Maintained in Closed and OpenSided Houses. International Journal of Poultry Science, 7:655-660.

Kanazawa, H., 2007. Role of vascular endothelial growth factor in the pathogenesis of chronic obstructive pulmonary disease. Medicine Science. Monit., 13: 189-195.

Khan, S. H. and R. Sardar, 2005. Effect of vitamin $\mathrm{C}$ supplementation on the performance of Desi, Fayoumi and commercial White Leghorn chicken exposed to heat stress. Pakistan Veterinary Journal, 25(4).

Konka, Y., F. Kirkpinar, E. Yaylak and S. Mert, 2008. Effects of dietary ascorbic acid on performance, carcass composition and bone characteristics of turkey during high summer temperature. Asian-Asut. Journal of Animal Science, 21: 426-433.

Kultu, H. R. and J.M. Forbes, 1993. Changes in growth and blood parameters in heat stressed broiler chicks in response to dietary ascorbic acid. Livestock Production Science, 36:335-350.

Laura, S., N. Bruijn and M. Rovers, 2009. Dietary bet glucans to fight chronic enteritis. World Poultry, 25: 14-16.

Lin, H., H. C. Jiao, J. Buyse and E. Decuypere, 2006. Stratigies for preventing heat stress in poultry. World's Poultry Science Journal, 62:71-85.

Lohakare, J. D., M. H. Ryu, T. W. Hahn, J. K. Lee and B. J. Chae, 2005. Effect of supplemental ascorbic acid on the performance and immunity of commercial broilers. Journal of Applied Poultry Research, 14: 10-19.

Marsh, J. A. and C. G. Scanes, 1994. Neuroendocrine-immune interactions. Poultry Science, 73:1049-1061.

McDaniel, C. D. and H. M. Parker, 2004. The effect of acetylsalicylic acid $n$ heat stress infertility of broiler breeder males. International Journal of Poultry Science, 9:570-577.

Mckee, J. S. and P. C. Harrison, 1995. Effects of supplemented ascorbic acid on the energy conversation of broiler chicks during heat stress and feed withdrawal. Poultry Science, 76:1278: 1286.

Mckee, J.S., P.C. Harrison and G.L. Riskowski, 1997. Effects of supplemental ascorbic acid on the energy conversation of broiler chicks during heat stress and feed withdrawal. Poultry Science, 76:1278:1286.

Mebta, R.K. and B. K. Sbingari, 1999. Feeding under heat stress. Poultry International, 38:68-77.

Mehmet, A., 2005. Effects of ascorbic acid on the performance and some blood parameters of Japanese Quails Reared Under Hot Climate Conditions. Turkish Journal of Veterinary Animal Science, 29: 829-833.

Mohammed A. A., 2010. Effect of acetyl salicylic acid (ASA) in drinking water on productive performance and blood characteristic of layer hens during heat stress. International Journal of poultry Science, 9 (4): 382-385.

Naseem, S., M. Younus, B. Anwar, A. Ghafoor, A. Aslam and S. Akhter, 2005. Effect of Ascorbic Acid and Acetylaslicylic Acid Supplementation on Performance of Broiler Chicks Exposed to Heat stress. International Journal of Poultry Science, 11: 900-904.

North, M.O. and D.D. Bell, 1990. Commercial chicken production manual, Foruth Ed. Van Nostrand Reinhold Puplisher, New York. U.S.A.

NRC, 1994. National Research Council. National Requirement of Poultry. 9th Rev. ed., National Academy Press, Washinggton, DC.

Pardue, S. L., J. P. Thaxton and J. Brake, 1985. Role of ascorbic acid in chicks exposed to high environmental temperature. Journal of Applied Physiology, 58(5):1511-1516. 
Pardue, S.L. and J.P. Thaxton, 1986. Ascorbic acid in poultry: a review. World's Poultry Science Journal, 42:107-123.

Payne, W.J.A. and R.T. Wilson, 1999. An introduction to animal husbandry in the tropic, Chapter 1: The effect of Climate, Black-well Science Publisher, Uk., pp: 324.

Pinar, T.S., 2008. The effect of dietary Turkish propolis and vitamin $\mathrm{C}$ on performance, digestibility, egg production and egg quality in laying hens under different environmental temperature. Asian-Aust. Journal Science, 21: 1164-1170.

Roussan, D.A., G.Y. Khwaldeh, R.R. Haddad, I.A. Shaheen, G. Salameh and R. Al Rifai, 2008. Effect of ascorbic acid, acetylsalicylic acid, sodium bicarbonate and potassium chloride supplementation in water on the performance of broiler chickens exposed to heat stress. Journal of Applied Poultry Research, 17:141-144.

Sahin, K., N. Sahin and M. Onderci, 2002. Vitamin E supplementation can alleviate negative effects of heat stress on egg production, egg quality, and digestibility of nutrients and egg yolk mineral cobcentrations of Japanese quails. Res. Veterinary Science, 73:307-312.

Sahin, K., M. Onderci, N. Sahin, M.F. Gursu and O. Kucuk, 2003. Dietary vitamin C and folic acid supplementation ameliorates the detrimental effects of heat stress in Japanese quail. Journal of Nutrition, 133(6): 1882-1886.

Sahin, K., N. Sahin and O. Kucuk. 2003a. Effects of chromium, and ascorbic acid supplementation on growth, carcass traits, serum metabolites, and antioxidant status of broiler chickens reared at a high ambient temperature $\left(32^{\circ} \mathrm{C}\right)$. Nutrition Res., 23:225238.

Sahin, K., N. Sahin, M. Onderci, F.M. Gurs and M. Issi, 2003b. Vitamin C and E can alleviate negative effects of heat stress in Japanese quails. Food, Agriculture \& Environment, 1:244-249.

SAS, Institute, 1996. SAS User's Guide: Statistics. SAS Institute Inc., Cary, NC. 6.12 Edition. SAS Institute INC., Cary, NC, USA.

Schwagar, J. and J. Schulze, 1998. Modulation of interleukin production by ascorbic acid. Veterinary immunol. Immunopatho., 164:45-57.

Seeman, M., 1991. Is vitamin C essential in poultry nutrition? Misset World poultry, 7:17-19.

Siegel, H.S., 1980. Physiological stress in birds. Bio Science, 301:529-533.

Stilborn, H.L., G.C. Jr. Harris, W.G. Bottje and P.W. Waldroup, 1988. Ascorbic acid and acetyl salicylic acid (A spirin) in the diet of broilers maintained under heat stress conditions. Poultry Science, 67:1183-1187.

Tayeb, I. T., 2009. Evaluation of productive and physiological performance of broiler subjected to physiological performance of broiler subjected to different methods to relieve heat stress. Ph.D thesis, Animal Resources Department. College of Agriculture and Forestry University of Mosul.

Tayeb, T. I., J. S.Yokhana and V.J.A. Amedy, 2011. Effect of ascorbic acid and potassium chloride supplementation on performance and some physiological parameters in broiler chicks reared under summer condition. International Journal of Poultry Science, 10: 247-250.

Tras, B., F. Inal, A. Bas, V. L.Altunok, M. Elmas and E. Yazar, 2000. Effect of continous supplementation of ascorbic acid, aspirin, vitamin $\mathrm{E}$ and selenium on some heamatological parameters and serum superoxide dismutase level in broiler chickens. British Poultry Science, 41:664666.

Tuleun, C.D., A.Y. Adenkola and T. Afele 2011. Effect of dietary ascorbic acid supplementation on the performance of Japanese (Coturnix coturnix japonica) quails in tropical environment. Journal of Animal \& Plant Science, 10: 1268-1275.

Uchiyama, M. and M. Mihara, 1978. Determination of malonaldehyde precursor in the tissues by thiobarbituric acid test. Analytical Biochemistry, 86: 271-278.

Usman, B.A., A.U. Mani and O.B. Muyiwa, 2008. Effect of dietary treatments of ascorbic acid on the blood parameters, egg production and quality in quail (Coturnix coturnix japonica) subjected to heat stress. International Journal of Poultry Science, 7:344-349.

Vila, V., V. Martinez-Sales, L. Almenar, I.S. Lázaro, P. Vila and E. Reganon, 2007. Inflammation, endothelial dysfunction and angiogenesis markers in chronic heart failure patients. International Journal of Cardiology, 27 [Epub ahead of print].

Wu, C. C., T. Dorairajan and T. L. Lin, 2000. Effect of ascorbic acid supplementation on the immune response of chickens vaccinated and challenged with infectious bursal disease virus. Veterinary Immunol. Immunopathol., 74:145-152.

Weissmann, G., 1991. Aspirin. Science Am., 264:84-90.

Whitehead, C. C. and T. Keller, 2003. An update on ascorbic acid in poultry. World's Poultry Science Journal, 59:161-184.

Yahav, S., A. Starschnow, I. Plavnik and S. Hurwitz, 1997. Blood system response of 
chickens to changes in environmental temperature. Poultry Science, 76:627-633.

Younis, D.T., 2007a. Effect of adding vitamin $\mathrm{C}$ to drinking water in the physiological and productive performance of broiler chickens reared under high temperature. Rafidain Agriculture Journal, 4: 40-46.
Younis, D.T., 2007b. Effect of adding vitamin $\mathrm{C}$ to drinking water to reduce the negative effect of heat stress in some productive performance of broiler chickens. Rafidain Agriculture Journal, 4: 47-53.

تأثير العوامل المضادة للإجهاد الحراري على النمو، المناعه واكسدة الليبيدات وبعض الصفات الفسيولوجيه

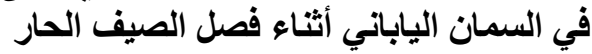

سيد أحمد عبد الفتاح', زينات عبد الجواد ابراهيم² 1- قسم إنتاج الدواجن, كلية النزراعة, جامعة عين شس، 2- قسم الدواجن, كلية النزراعة, جامعة الزقازيق

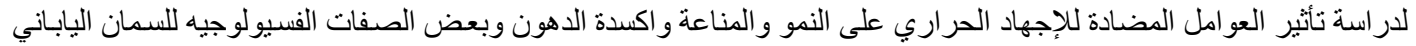

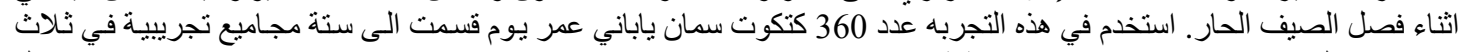

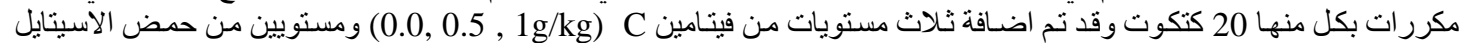

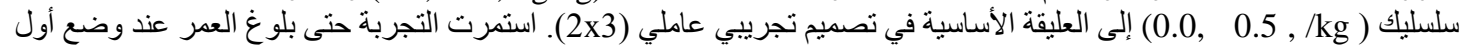
بيضة (العمر عند النضج الجنسي).

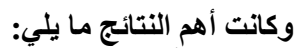
سجل أفضل وزن جسم ووزن جسم مكتسب وكذلك أفضل معدلات تحويل غذائي في نهاية التجربة لمجمو عات الطيو الطيور المغذاة علي

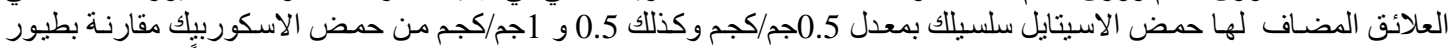

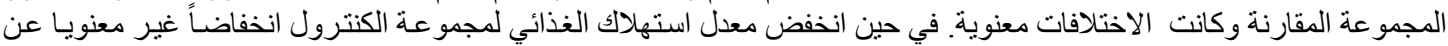

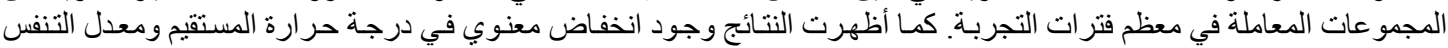

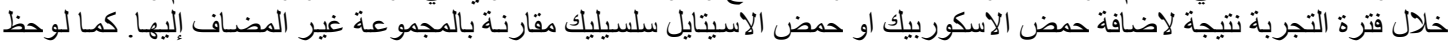

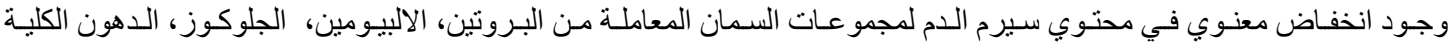

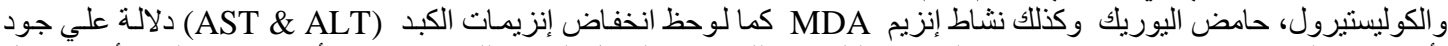

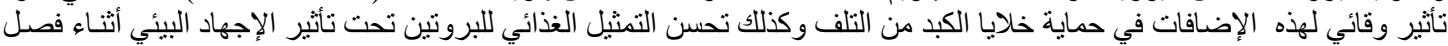

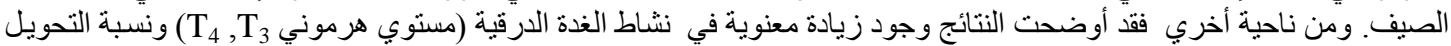

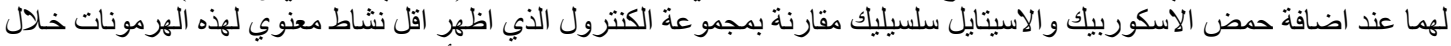

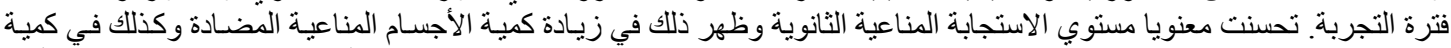

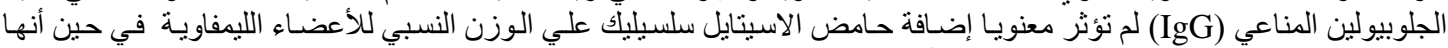

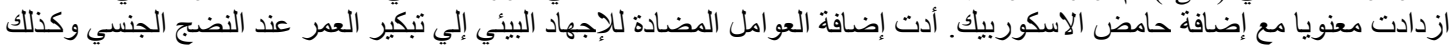

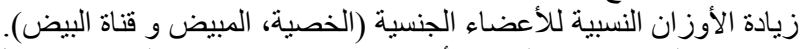

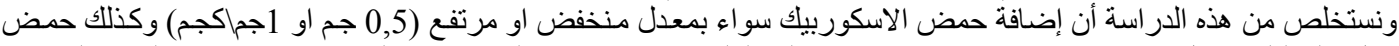

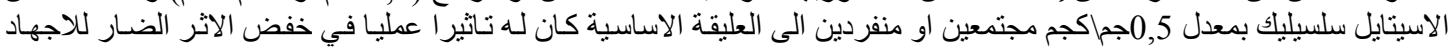

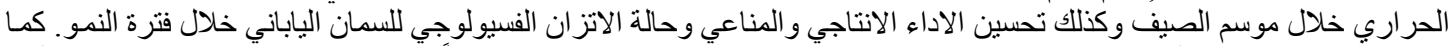

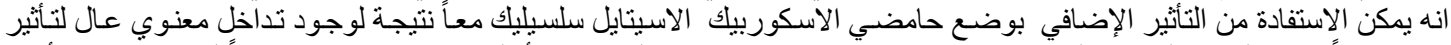

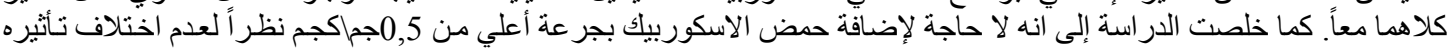

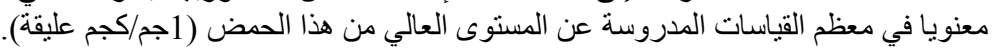

